This item was submitted to Loughborough's Research Repository by the author.

Items in Figshare are protected by copyright, with all rights reserved, unless otherwise indicated.

\title{
Outsiders looking in and insiders looking out: A comparative study of newspaper coverage of Italian-German relationships in the 2013 elections
}

\section{PLEASE CITE THE PUBLISHED VERSION}

https://doi.org/10.1080/23248823.2018.1435198

\section{PUBLISHER}

Taylor \& Francis @ The Founding Editors, Contemporary Italian Politics

\section{VERSION}

AM (Accepted Manuscript)

\section{PUBLISHER STATEMENT}

This is an Accepted Manuscript of an article published by Taylor \& Francis in Contemporary Italian Politics on 06 Feb 2018, available online: https://doi.org/10.1080/23248823.2018.1435198

\section{LICENCE}

CC BY-NC-ND 4.0

\section{REPOSITORY RECORD}

Vaccari, Cristian, and Claudius Wagemann. 2019. "Outsiders Looking in and Insiders Looking Out: A Comparative Study of Newspaper Coverage of Italian-german Relationships in the 2013 Elections". figshare. https://hdl.handle.net/2134/28391. 


\title{
Outsiders Looking In and Insiders Looking Out A Comparative Study of Newspaper Coverage of Italian-German Relationships in the 2013 Elections
}

Cristian Vaccari (Loughborough University) and Claudius Wagemann (Goethe University Frankfurt)

\begin{abstract}
We conceptualise transnational political communication as an emerging phenomenon in globally connected polities, whereby public discourse in a country increasingly focuses on politics, policies, and political actors in other countries. There are two dimensions to transnationalisation: "outside-in", when political communication focuses on the domestic politics of foreign countries, and "inside-out", when foreign countries play a role in a country's domestic public discourse. We apply this conceptual distinction to a study of newspaper coverage of the 2013 German and Italian elections in both countries. Based on a content analysis of 428 articles across six newspapers, we find that Germany received more, and more positive, coverage in the Italian press than Italy did in the German press. While the German press tended to be neutral and to cover Italy only as part of Italy's own electoral politics, the Italian press intensely covered Germany during both the German and Italian elections. Articles in the inside-out mode of transnationalisation were more likely to discuss the interdependencies between the two countries, but those articles could only be found in the less powerful Italy, whereas they were nearly absent in the more powerful Germany.
\end{abstract}

Keywords: political communication, transnationalisation, Italy, Germany, Europe, media, public sphere, 2013 elections

\section{Introduction}

"Più Italia, meno Germania"-More Italy, less Germany—was the slogan with which the Italian political party Forza Italia launched its European election campaign in late April 2014. ${ }^{1}$ The slogan, printed in the party's official posters and social media graphics, aimed to channel widespread criticism among the Italian electorate of Germany's leadership role during the Eurozone crisis, which had resulted in the tightening of fiscal policies and cuts to social expenditures in Italy. German politicians from several parties vocally complained about Forza

\footnotetext{
1 We are grateful to Mascia Mazzanti and Nils Sartorius, who coded the Italian and German newspaper articles, respectively. We are also grateful for the useful feedback we received from the participants of the DAAD workshop 'Populism, Prejudices and Perspectives: Italy and Germany in Today's Europe', held at the Goethe University Frankfurt in November 2016, where we presented an early version of this article.
} 
Italia's slogan and several news outlets took up the story. ${ }^{2}$ During his 20 year-long presence in Italian politics, Silvio Berlusconi has often provoked criticism; but rather than a sudden outburst or a more or less involuntary gaffe, this poster seems to be part of a coherent strategy. Indeed, when presenting Forza Italia's candidates for the upcoming European Parliament elections, Berlusconi made a joking reference to Martin Schulz, the European Socialists' party leader and candidate for Chair of the European Commission, recalling a famous conflict between the two: during the inaugural session of Italy's presidency of the European Council in 2003, Schulz, who was then a member of the European Parliament, forcefully criticised then Prime Minister Berlusconi's conflict of interests and mass media ownership. Berlusconi famously replied that he knew a movie producer who was going to make a film about Nazi concentration camps and that he would recommend Schulz for the role of the kapo (i.e. a prisoner fulfilling administrative functions for the camp authorities). Eleven years later, Berlusconi recalled and re-enacted this episode in his pre-electoral press conference, claiming that, when he referred to concentration camps, "the sky fell, because according to Germans, concentration camps never existed". ${ }^{3}$

Outraged politicians across Germany, Italy, and the rest of Europe quickly joined in condemning Berlusconi's statement, which featured heavily in political news coverage across the continent. It can only be suspected at this point whether the temporal coincidence of Forza Italia's electoral poster and Berlusconi accusing the Germans of being Holocaust deniers is part of a broader discursive strategy. ${ }^{4}$ Berlusconi's gaffe can be seen as part of a campaign strategy that his and other parties had pursued at least since the 2013 general election: that of blaming Germany for most of Italy's and the Eurozone's problems. It is revealing that Berlusconi chose not to attack the European Union as a supra-national structure, which is what euro-sceptical and nationalist parties such as the UK Independence Party and the French Front National ${ }^{5}$ usually do, but rather directly to challenge a particular member state. This incident is not an isolated example, but the sign of an increasingly common tendency towards what has been called Horizontal Europeanisation (Koopmans and Erbe 2004). The adjective 'horizontal' differentiates this form of Europeanisation from its, hitherto more common, vertical variant, which articulates the relations between supra-national and national levels of governance. In our view, this tendency towards an increasing focus on relationships (including conflicts) between individual states, vis-à-vis transnational governance bodies, is not necessarily limited to Europe, although the various connections resulting from EU membership create a specific set of interdependencies between countries. Recent examples of public controversies between individual states abound: discussions of alleged Russian interference in the 2016 United

\footnotetext{
2 Posters with the slogan have been deleted from Forza Italia's website, but they can still be found on its official Facebook page at https://www.facebook.com/ForzaltaliaUfficiale/photos/a.298792176929683.1073741826.172265396249029/389097767899123/ (accessed 14 August 2017).

3 See http://www.reuters.com/article/us-italy-berlusconi-germany-idUSBREA3P0G620140426 (accessed 10 August 2017 ).

${ }^{4}$ Note that both incidents happened the day after the Italian national holiday, when the liberation of Italy from Nazi forces is remembered.

5 The Front National's European election campaign slogan was "More France, less Europe."
} 
States presidential elections; the general presentation of the Trump presidential campaign and administration, international coverage of US internal race disputes, or questions about gun laws which affect other countries only marginally; the then US President Barack Obama's intervention during the 2016 referendum campaign on Brexit; or discussion about relationships and alliances between Russia and its President and various national political parties in Germany, France, and Italy. Therefore, we conceptualise transnationalisation of political communication as a broader phenomenon that extends beyond the EU. While a trend towards the transnationalisation of campaigns may be expected in the case of European elections, it has also become a feature of national elections that politics and politicians of other countries become salient.

There is also a normative dimension to our considerations. On the one hand, it is certainly desirable for the spirit of European integration, and transnational governance in general, that there is mutual attention to other countries' politics and politicians. However, if transnationalisation results in greater stereotyping of other countries, it may easily become a tool for a populist re-nationalisation of political rhetoric, making transnational governance more difficult as a result.

Transnationalisation can be explained by different factors, chief among which are the strategies of political elites and the choices of the news media in determining what issues, institutions and politicians to cover and how. To some extent, these two sets of actors are related, as politicians can be expected to follow the media logic to achieve visibility in the news, while journalists generally take cues from politicians to orient their coverage, especially during elections. Thus, analysing transnationalisation requires first and foremost the study of news media coverage of politics in different countries.

In this article, we employ a two-by-two comparative approach to analyse transnationalisation dynamics in newspaper coverage of two countries at the core of the European Union: Germany and Italy. These two countries are not only very strongly intertwined in policy and political terms, but also present theoretically relevant differences in the structure of opportunity that their political and media systems provide for different types of transnationalisation to take shape.

First, we analyse how the press in one country covers the other country's general election campaign; we call this 'outside-in' transnationalisation, as on those occasions public debate in one country looks outside to another. Thus, transnationalisation starts from the outside, with a campaign taking place in a foreign country, and newspapers bring some aspects of this foreign campaign into the domestic debate of their own country. This pattern of "outsiders looking in" does not necessarily entail a public dialogue between those countries.

Second, we analyse how the press in one country, in covering its own national election, portrays a foreign country and its politicians. We call this 'inside-out' transnationalisation, because newspapers take the occasion of an internal event to look out to a foreign country and convey inputs from institutions and politicians from that 
country. This scenario entails some potential for transnational dialogue between politicians and populations of different countries.

We employ these concepts to derive research questions and hypotheses on the dynamics of transnational election campaigns in the context of the 2013 general elections in Italy and Germany. We address our questions and hypotheses by deploying quantitative content analysis of the relevant articles published in the three main newspapers in each country during both campaigns.

\section{Conceptual framework}

Koopmans and Erbe (2004) identify four crucial functions that media play in the European policy process: legitimising European institutions and actors by making them visible to citizens subject to their decisions; facilitating responsiveness by informing elites of citizens' priorities and preferences; enhancing accountability by allowing the public to form opinions about the performance of European institutions; and facilitating participation by allowing social movements, civic organizations, and NGOs to make their views known to the public. The debate on how media perform these functions has often focused on the plausibility of a "European public sphere", modelled after national public spheres, but, as has been aptly observed, "the more realistic scenario is not that of a genuinely supranational European public sphere in the singular, but the Europeanization of the various national public spheres." (Koopmans and Erbe 2004: 100) This, in turn, could occur in the form of a greater focus on European-wide issues and actors by national media; of coverage of these issues from a perspective that includes more than one country; or of "increased attention to public debates and mobilization in other member states" (Koopmans and Erbe 2004: 101), consistent with the large, and arguably growing, role of intergovernmental policymaking in the Union. The question to be asked is then whether public discourse, and specifically news coverage, is keeping up with these developments.

Koopmans and Erbe distinguish two degrees of horizontal Europeanisation: 'weak', when national media cover politics in other countries but without addressing the relationships between the domestic and foreign country; and 'strong', when such a connection is articulated and "actors in one country explicitly address or refer to actors or policies in another member state." (Koopmans and Erbe 2004: 101) In an analysis of German media in the year 2000, they find evidence of moderate degrees of both variants. The vertical one was more common than the horizontal one (i.e., EU institutions were covered more than other states), and the weak variant of horizontal Europeanisation (i.e., coverage of other countries' politics without explicitly articulating links with, in this case German, domestic politics) prevailed over the strong one (where such link is discussed).

Koopmans and Erbe's work is both theoretically insightful and empirically relevant, but it also has some limits. At the theoretical level, it does not explicitly address the possibility that horizontal Europeanisation could be purposefully 'weaponised' for electoral gain. Indeed, the prolonged crisis of European integration in the face of 
the Eurozone's financial difficulties and other challenges, such as migration, have turned European integration into a potentially contested issue, leading some (Kriesi et al. 2012; Hooghe and Marks 2009; Marks and Wilson 2000) to call this a new electoral cleavage. As election campaigns offer a forum for politicians to articulate those divisions, for voters to learn and form an opinion about them, and for the media to inform citizens about them, we can expect that dynamics of horizontal Europeanisation should be particularly visible during campaign periods. Additionally, national elections can contribute to horizontal Europeanisation by incentivising parties and candidates to address, or even take sides in, another country's competition, or to refer to their counterparts in another country to lay blame or praise on them, possibly with an eye to their own domestic politics. Although these flows of information take opposite directions, both are forms of horizontal Europeanisation (or transnationalisation) and can manifest themselves in their strong or weak variant.

\section{Research Design}

Studying transnationalisation means to apply a dyadic approach, examining how political communication flows both within and across two countries. Germany and Italy differ in terms of their political systems, media systems, and public opinion regarding European integration and, in particular, the management of the Eurozone crisis. There are many reasons to expect that German and Italian politics may come into play in each other's election campaigns. They share a long history of alliances, trade relations, and cultural exchange, not least through tourism, as well as a wide set of reciprocal stereotypes and long-running jokes and mockeries. They are two of the six founding members of the European Coal and Steel Community, a precursor to the EU, and two key actors in the financial, economic, and political crises that affected the Eurozone from 2008 onwards. In particular, Germany is the leading economic power and a strong supporter of strict monetarist policies, while Italy is one the most troubled economies in the Eurozone, with a public debt whose size is often said to make it "too big to save". Moreover, both countries held elections in 2013, with only a few months between the vote in Italy (February) and Germany (September). This temporal closeness implies that many contextual features did not change substantially between the two moments. What is more, the Eurozone crisis was not 'hot' during the election year, i.e., no rescue package had to be prepared, no emergency summit was held, and the general climate was not exclusively oriented towards the crisis.

Besides being strongly related to each other in political and policy terms, Germany and Italy also feature theoretically relevant differences in the opportunity structures their political and media systems create for different types of transnationalisation. First, in terms of politics, while there was substantial unity among German elites about the country's approach to the Eurozone crisis, the main Italian parties diverged widely in their approach to the issue, and, importantly, in their assessment of Germany's role in the crisis. Moreover, Italian politicians had some incentives to find an external agent to blame for the country's economic woes, while 
German politicians felt little need for that as the country had experienced robust growth in previous years. Second, in terms of the media system, news outlets in Italy are closely embedded within specific political parties, or tend to represent certain political viewpoints, while most German media organisations do not align directly with a party or ideology. The features of Italian media favour a style of journalism more geared towards commentary than reporting and may result in a greater tendency to portray other countries' institutions and politicians in a less neutral way than what can be expected in Germany given the greater separation between media and politics characterising its media system. We further elaborate on the potential impact of these crosscountry differences in the next paragraph.

Given the novelty of these phenomena and of the approach we propose, our study is exploratory. Our research design is illustrated in Table 1. As we will discuss further on in the article, we chose to focus on newspaper coverage as an indicator of the overall public discourse. The vertical axis divides our data by country: to learn about coverage of Germany during Italy's campaign (quadrant A) and the representation of Germany's election in Italy (quadrant $\mathrm{C}$ ) requires studying Italian newspapers. Conversely, to assess the corresponding dynamics in quadrants B and D, we need to look at German newspapers. The horizontal axis differentiates between the modes of transnationalisation: quadrants A and B refer to the inside-out mode, by which a foreign country's policies and politicians are discussed during a country's general elections; quadrants $C$ and $D$ entail the outsidein mode, by which the foreign country's national election is discussed.

Table 1 - Research design

\begin{tabular}{|l|l|l|l|}
\hline & & \multicolumn{2}{|l|}{ Country whose newspaper coverage is analysed } \\
\hline & & Italy & Germany \\
\hline \multirow{3}{*}{$\begin{array}{l}\text { Mode of } \\
\text { transnationalisation }\end{array}$} & $\begin{array}{l}\text { Inside- } \\
\text { out }\end{array}$ & $\begin{array}{l}\text { A } \\
\text { Mentions of Germany in Italian } \\
\text { newspapers' coverage of Italian } \\
\text { elections }\end{array}$ & $\begin{array}{l}\text { B } \\
\text { Mentions of Italy in German } \\
\text { newspapers' coverage of } \\
\text { German elections }\end{array}$ \\
\cline { 2 - 4 } & $\begin{array}{l}\text { Outside- } \\
\text { in }\end{array}$ & $\begin{array}{l}\text { C } \\
\text { Coverage of German elections in in } \\
\text { Italian newspapers }\end{array}$ & $\begin{array}{l}\text { D } \\
\text { Coverage of Italian elections in } \\
\text { German newspapers }\end{array}$ \\
\hline
\end{tabular}

\section{Theory, Research Questions and Hypotheses}

Research on public discourse in Europe has mostly focused on the vertical dimension of EU institutions and governance, while neglecting the transnational dimension on which we focus here. However, studies have shown that media coverage of European Union governance affects public opinion on those issues (De Vreese 
and Boomgaarden 2006; Schuck and De Vreese 2006; Vliegenthart et al. 2008), and it is plausible that the same applies to transnational coverage of foreign countries' elections (outside-in transnationalisation) and, perhaps especially, of discussions of foreign countries in domestic electoral debates (inside-out transnationalisation). We know little about the characteristics of transnational coverage, apart from the fact that horizontal Europeanisation tends to be less prominent than vertical Europeanisation (Koopmans and Erbe 2004). It is thus worthwhile to explore the German and Italian media coverage of the other country, focusing on both its amount and tone:

RQ1: Were the amount and tone of coverage of German and Italian politics by the other country's newspapers balanced or skewed between the two countries?

From this, we derive three specific hypotheses, one regarding the amount of coverage, the other two its tone.

When it comes to the amount of media coverage, we expect German politics to be covered more intensely in the Italian press than Italian politics in the German press. Germany plays a larger role in current European Union politics than Italy, and therefore it has greater power to influence Italian politics than Italy has to influence German politics. According to the theory of news values (Gans 1979), journalists decide what topics to cover based on often implicit assumptions about its content, context, and main characters involved. Both Galtung and Ruge (1965), in their classic analysis of news values, and Harcup and O'Neill (2001), in their more recent application of the model, conclude that countries and actors that are considered more powerful are more likely to be covered in the news. Moreover, the indexing theory (Bennett 1990) argues that media tend to reflect elite opinions, especially when they are in agreement, and there was wide elite consensus in both countries about the central role of Germany and the smaller, even dependent, role of Italy in the Eurozone crisis. (Among Italian politicians there was disagreement about the positive or negative effects of German policies in this domain, but little contestation of the fact that Germany had more power than Italy). Also, Italian politicians had greater incentives to discuss Germany's role than German politicians had to focus on Italy. This is because politicians facing difficult domestic conditions and policy failures have a better chance to preserve their power if they convince the public that external forces that they cannot control are to be blamed than if they try to convince the electorate that the situation is better than they think ( Hood 2010). The different economic predicaments of the two countries at the time of the election - with Italy facing a deep and prolonged recession and Germany enjoying notable prosperity - suggest that Italian politicians had substantial incentives for shifting some blame to Germany, whose continuous support for austerity policies could be presented as an unwelcome and uncontrollable external circumstance. Moreover, the outgoing government in Italy was supported by a grand coalition so that numerous parties across the political spectrum faced the prospect of bearing some responsibility for the economic downturn and cuts to social expenditure and thus had incentives to shift some of that blame to outside factors. The Italian public was indeed receptive to these ideas: according to a survey conducted by the Pew Research Global Attitudes Project (2012), 39\% of Italians considered the power that Germany and other 
European Union countries had on Italy to be a "major threat" to their country's well-being, 35\% called it a "minor threat", and only 19\% claimed that it was not a threat at all. (Incidentally, the same survey found that $71 \%$ of Germans considered economic problems in Greece and Italy to be a "major threat" to their country's well-being). Hence, we formulate the following hypothesis:

H1a: The discussion of German politics in Italy exceeded that of Italy in Germany.

As for the tone of media coverage, comparative research on Western media systems (Hallin and Mancini 2004) suggests that Italian media are more likely to support, and advocate, specific political viewpoints than German media. Van Kempen (2007) measured media political parallelism at the audience level, i.e. the degree to which newspaper readers and television watchers select media outlets in light of their political predispositions, across fifteen European countries, and ranked Italian newspapers as fourth and German newspapers as fifteenth (last). The fact that partisan fault lines clearly differentiate the readerships of Italian newspapers indicates that their content is likely to reflect particular viewpoints rather than appealing to readers of different opinions, and the reverse can be argued for German newspapers. Therefore, we expect that coverage of Italian politics by German media is more neutral than coverage of German elections and politics by Italian media.

However, there are also reasons to believe that, when it comes to the focus of our analysis, German media may be less neutral than Italian ones. The indexing theory discussed earlier (Bennett 1990) suggests that media coverage tends to reflect elite opinions, and that, when elites agree on certain issues, those are not presented as controversial in the press. German elites have historically been rather suspicious of Italian political institutions and actors, and they had clear views of at least two of the leading Italian 2013 election contenders: a favourable opinion of Mario Monti, and a rather unfavourable one of Berlusconi, not least due to the reasons discussed at the beginning of this article. Moreover, the German press may also have covered Italian politicians negatively to reflect its readers' general opinions. When Germans were asked in a survey to name the three European countries where people were the most corrupt and the least hard-working, $60 \%$ and $45 \%$, respectively, named Italy, placing it in first and second place among all EU countries (Pew Research Global Attitudes Project, 2012). By contrast, Italian elites were more divided with respect to their evaluations of the role played by Germany in Europe, ranging from enthusiastic supporters (Monti) to cautious Europhiles (the centre-left Democratic Party) to very critical centre-right and populist parties. Moreover, public opinion in Italy was rather favourable to Germans: according to the survey cited above, Germany received $62 \%$ of mentions among Italian respondents as the European country where people are most hard-working, and $36 \%$ of mentions as the country with the least corrupt population: in both cases, Germany was the most popular choice among Italians (ibidem).

Based on these considerations, we developed two hypotheses on the tone of coverage of Germany and Italy. The first, building on comparative research on media systems and news coverage, suggests that the Italian press was less likely to treat Germany in a neutral way, while we expect the German media to cover Italy more 
neutrally. The second, based on the differences between the opinions of both elites and the public in the two countries, postulates that, among articles taking a non-neutral stance about the other country, the German press features more negative stories about Italy than vice versa.

H1b: The Italian press expressed fewer neutral judgments of Germany than the German press of Italy.

H1c: Among articles expressing non-neutral judgments, the German press published a larger share of articles conveying a negative judgment of Italy than the Italian press of Germany.

We also explore the differences between the two modes of transnationalisation we have identified. To study the inside-out mode, we assess the extent to which German politics and politicians were covered by Italian newspapers during Italian elections and, conversely, the ways in which German newspapers referred to Italian politics and politicians during the German elections. To study the outside-in mode, we assess the coverage of German elections by Italian newspapers and of Italian elections by German newspapers. Since no research we are aware of has purposefully compared these forms of transnationalisation, we cannot rely on existing theories and research to derive strong expectations about them. Thus, we start from a preliminary, open research question on the relative weight of these two modes in each country.

RQ2: Is outside-in or inside-out transnationalisation prevalent in the German and Italian press?

We also return to the distinction between 'strong' and 'weak' variants of Europeanisation (Koopmans and Erbe 2004). Our conceptual framework can incorporate this dimension, as the relationships between countries can be mentioned explicitly or not in both forms of transnationalisation. In the inside-out mode, an example of the strong variety is to decry Germany's interference in the Italian campaign, while the weak variety is exemplified by a comparison between the German and Italian economic growth rates without arguing that German policies affect Italy. In the outside-in mode, the strong variety of transnationalisation occurs when, for instance, the German press suggests that the victory of a certain party may destabilise the Eurozone, with negative repercussions for Germany. An example of the weak variety is a news report by an Italian newspaper on the German campaign, devoid of any references to its implications for Italy. We hypothesise that the political connections between two countries are more likely to be discussed in the inside-out mode of transnationalisation, when a foreign country is covered within another country's domestic elections, than in the outside-in mode, when a foreign country's campaign is monitored:

$\mathrm{H} 2$ : The strong variant of transnationalisation is more common in the inside-out than in the outside-in mode. 


\section{Data and Methods}

Citizens experience election campaigns mostly through media coverage rather than by listening directly to politicians' speeches, let alone by reading party manifestos or directly interacting with candidates. Therefore, an analysis of media coverage of the elections is the most appropriate way to study public discourse for the purposes of our research. Newspaper articles, in turn, are a good representation of public discourse. Although most citizens in contemporary Western democracies access the news through television, newspapers are still quite relevant in the countries we are studying. According to the Reuters Institute for the Study of Journalism (2013), in 2013 63\% of Germans and 59\% of Italians used print newspapers as news sources at least on a weekly basis. In both countries, newspapers are the third most common news source after television and the Internet, where many citizens get their news through newspapers' websites.

Studying newspaper articles has various advantages. First, newspapers still tend to set agendas that other media follow. Second, compared to television, newspapers feature more news stories and are thus more likely to provide a substantial body of content that can be used to address our questions and hypotheses. Finally, newspaper articles are generally available in publicly accessible online archives, which made our data collection easier and allows for the replication of our findings. However, we are also aware of the drawbacks of this strategy which limit the generalisability of our study. First, newspapers mostly reflect elite-centric discourse, so citizens' perspectives, which could be captured for instance by analysing social media content, cannot be incorporated. Secondly, as discussed above, most citizens get their news via television and the Internet; and even though we have reason to believe the agenda of news organisations operating online and on the airwaves does not differ substantially from the one we could reconstruct here, we cannot directly speak to that. Thirdly, although we selected three of the most relevant newspapers in each country, gossip magazines and other entertainmentoriented publications are much more popular, and to the extent that they occasionally cover politics they may be more consequential than newspapers (Mazzoni and Ciaglia 2014). A further development of our exploratory study would address all these limitations, by covering political news on television and on the Internet, entertainment magazines, and social media.

The Italian elections were held on 24 and 25 February 2013. We began collecting articles on 6 December 2012, when Berlusconi announced his intention once again to lead the centre-right coalition. This was not the official date of the start of the campaign (which is technically 45 days before Election Day), but it was a critical juncture, as Berlusconi added a controversial dimension to the campaign (both in Italy and abroad). We analysed newspaper articles published until 3 March 2013, one week after the elections, so as to capture discussions of the election outcome and its implications. The German elections were held on 22 September 2013. There was no campaign event comparable to Berlusconi's announcement, neither is there an official starting date of the campaign in Germany. Therefore, we pragmatically set our timeframe, so that the length of time covered 
corresponds to the Italian case, and collected articles published between 1 July 2013, and 1 October 2013, again including the first week after the vote.

We selected newspapers to include both the most popular outlets and a diversity of viewpoints. In both countries, we chose the two main nation-wide quality dailies, namely Corriere della Sera and la Repubblica in Italy and the Süddeutsche Zeitung (SZ) and the Frankfurter Allgemeine Zeitung (FAZ) in Germany. Additionally, we analysed the main German tabloid, the Bild, and, since there is no widely read tabloid in Italy, we added // Giornale, owned by Berlusconi's family. Given the anti-German stance adopted by Berlusconi, we expected I/ Giornale to provide a different viewpoint from the other two Italian newspapers, which had applauded the cross-party Monti government (Corriere) and were historically supportive of the left (Repubblica). In both countries, the three newspapers are among the most-read dailies. While our strategy makes it possible to include a sample of different viewpoints advocated by these newspapers, we have not enlarged our analysis to cover the whole political spectrum, as the media themselves are not the object of our analysis, but the means to capture public discourse.

Online archives were accessible for free in the case of Corriere, Repubblica, FAZ and SZ; in the case of Giornale and the Bild, we used the online search function, since no free archives exist. However, at the time of our data collection, articles from the above-mentioned periods were still accessible through a free search. Since the search function for these two outlets only included articles published in their online editions, the findings from these publications are not fully comparable with those from the first four. In all the newspaper archives, we searched for articles using terms which we had pre-tested and established to be well suited to capture articles on the Italian and German elections and politics. We also included additional articles obtained as a result of supplementary searches with keywords representing the main party leaders. After manual checks on all articles to establish that they were indeed relevant to our topic, our corpus consists of a total of 428 articles, of which $258(60 \%)$ are from Italian newspapers and 170 (40\%) from German newspapers.

Our codebook differentiated between two unitis of analysis: articles, and mentions of politicians. A total of 933 politicians were mentioned in the articles. On average, German articles mentioned 5.6 Italian politicians, while Italian articles mentioned 1.5 German politicians. Because the Italian party system is much more fluid and fragmented than the German one, German journalists needed to include a greater number of Italian politicians in their coverage of Italy than Italian journalists did.

We assessed each article on the basis of 18 variables. The coding was performed independently by the German and Italian research teams after an extended period of conceptual development and testing that helped us refine our categories and establish mutual understandings of how to operationalise them. Due to space constraints, we cannot discuss results for all our variables, but our analysis will focus on the following:

- mentions of economic issues; 
- mentions of the current state and/or future of European integration;

- the tone of the article, that is, whether the other country was overall treated positively (e.g. as a model country, as performing well, as implementing useful reforms, etc.), neutrally, or negatively (e.g. as not doing what is expected, as showing worse economic performance, as a country likely to cause problems in the future, etc.);

- $\quad$ the comparative judgment emerging from the article, that is, whether one country was portrayed as being superior or inferior to the other in terms of three different aspects, each coded in terms of separate variables: the economy, the political system and institutions, and stereotypes about its population;

- the evaluation of the countries' reciprocal influence, that is, whether the home country was generally portrayed as having positive or negative effects on the other country; and whether the other country was generally portrayed as having positive or negative effects on the home country;

- whether the article mentioned one or more politicians; when it did, we also coded: names of politicians; adjectives describing them, and evaluation of the politician (positive, neutral, or negative).

Table 2 - Descriptive statistics of newspaper corpus

\begin{tabular}{|c|c|c|c|c|}
\hline & & \multicolumn{2}{|c|}{ Country whose newspaper coverage is analysed } & \multirow[b]{2}{*}{ Total } \\
\hline & & Italy & Germany & \\
\hline \multirow{2}{*}{ Mode of transnationalisation } & Inside-out & $\begin{array}{l}\text { Corriere (55 articles) } \\
\text { Repubblica (53 articles) } \\
\text { Giornale (30 articles) } \\
\text { Total: } 138\end{array}$ & $\begin{array}{l}\text { SZ ( } 3 \text { articles) } \\
\text { FAZ ( } 2 \text { articles) } \\
\text { Bild ( } 0 \text { articles) } \\
\text { Total: } 5\end{array}$ & 143 \\
\hline & Outside-in & $\begin{array}{l}\text { Corriere (45 articles) } \\
\text { Repubblica (56 articles) } \\
\text { Giornale (19 articles) } \\
\text { Total: } 120 \\
\end{array}$ & $\begin{array}{l}\text { SZ (63 articles) } \\
\text { FAZ (77 articles) } \\
\text { Bild ( } 25 \text { articles) } \\
\text { Total: } 165\end{array}$ & 285 \\
\hline Total & & 258 & 170 & 428 \\
\hline
\end{tabular}




\section{Findings}

RQ1 asks whether the amount and tone of coverage of Germany and Italy in the other country's newspapers are balanced or skewed between the two countries, while H1a predicts that the discussion of German politics in Italy exceeded that of Italy in Germany.

As Table 2 above shows, 258 Italian articles discussed Germany while only 170 German articles discussed Italy (Italy/Germany ratio of 1.52); this difference, assessed through a $\chi^{2}$ test on equal distribution, is highly significant $\left(\chi^{2}=18.1^{\star \star *}, \mathrm{df}=1\right)$. However, if we focus on the outside-in mode of transnationalisation, German newspapers covered Italian elections more intensely than Italian newspapers covered German elections (ratio of 120/165 = 0.73; $\left.\chi^{2}=7.1^{\star \star}, \mathrm{df}=1\right)$. For the inside-out mode this ratio is no less than $27.60\left(138 / 5 ; \chi^{2}=123.7^{\star \star \star}, \mathrm{df}=1\right)$, with Italy covered in only five German newspaper articles during the German elections. So, while the German press reported intensively on the Italian elections, Italy did not feature in domestic coverage of the German elections. The almost complete lack of mentions of Italy, a crucial economic and political partner in EU politics, in coverage of the German election is a remarkable finding, to which we come back in our conclusions. Unfortunately, this also means that we are not able fully to assess the differences between the two modes of transnationalisation in comparative perspective, as we only have limited data on the inside-out mode in Germany.

Coverage of the Italian election, by contrast, included many references to Germany. H1a is therefore confirmed only with respect to the inside-out mode, as German politics featured more heavily in coverage of Italian elections than Italian politics did in the domestic coverage of German elections. However, $\mathrm{H} 1 \mathrm{a}$ is not confirmed when it comes to the outside-in mode, as the Italian election received more coverage in German newspapers than the German election did in Italian newspapers.

Our next hypotheses claim that the Italian press was less likely to express neutral judgments of Germany than the German press about Italy ( $\mathrm{H} 1 b)$, and that, among articles expressing non-neutral judgments, the German press published a larger share of articles conveying a negative judgment of Italy than the Italian press of Germany ( $\mathrm{H} 1 \mathrm{c}$ ). Figure 1 shows that, in most articles, the other country was treated neutrally. In particular, more German newspapers' articles were neutral than Italian ones: 84.1\% versus 64.2\%. Following a two-proportion z-test (Kanji 2006: 27), this is significant $\left(z=4.49^{\star \star \star}\right)$. These findings confirm H1b. 
Figure 1 - Treatment of the Other Country ${ }^{6}$

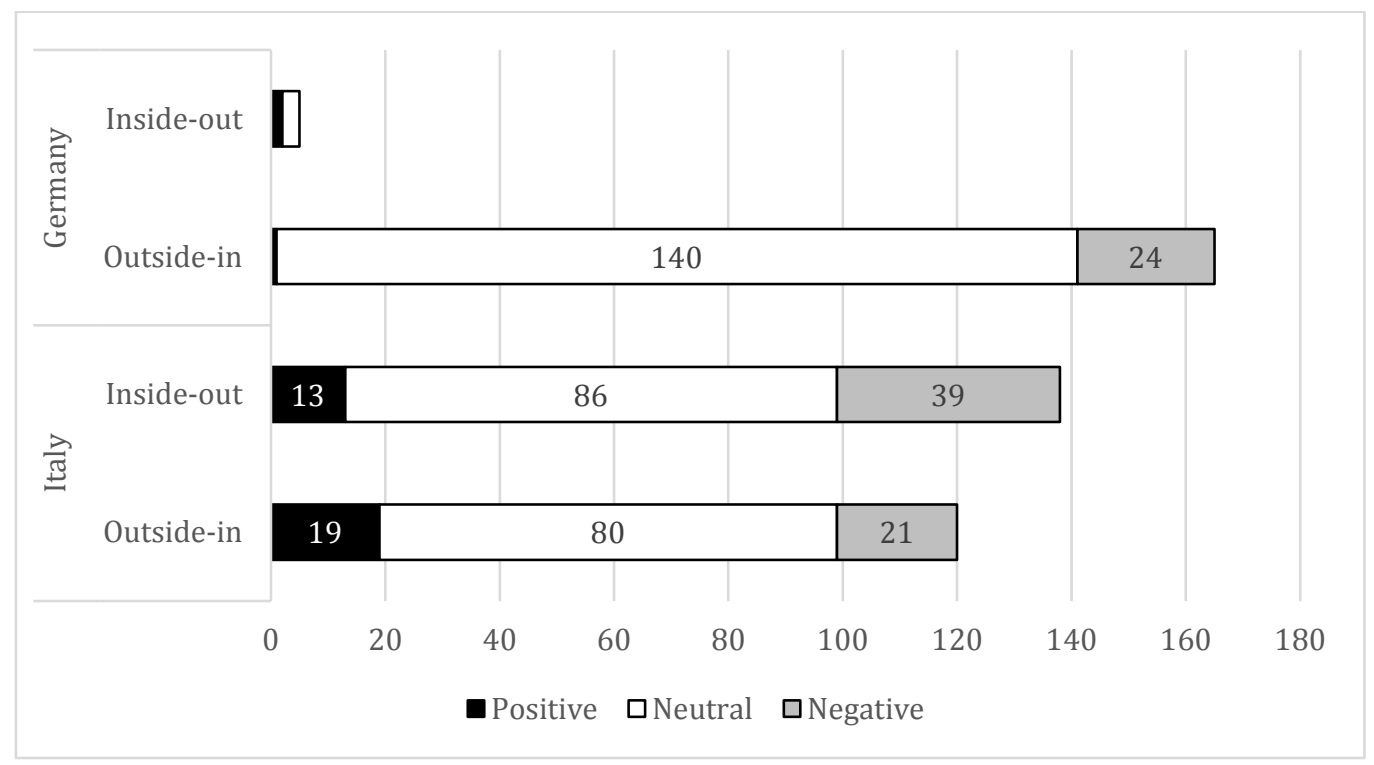

Figure 1 also shows that, among stories that were not classified as neutral, negative stories were more common in Germany (24 out of 27 stories; 88.9\%) than in Italy (60 out of 93; 65.2\%). H1c is, therefore, confirmed, and the difference between the two countries is significant $\left(z=2.38^{\star}\right)$. However it is remarkable that, among nonneutral stories, negative treatments of the other country prevailed in both Germany and Italy.

Our data also allow us to differentiate between general evaluations and the discussion of specific aspects, such as the economy. In approximately a third of all Italian articles (81 out of 258), Germany is mainly addressed with respect to the economy, while this is the case for more than half (93 out of 170) of all German articles focusing on Italy. Thus, transnationalisation is mainly economic. Most articles did not openly portray one country as economically superior to the other but, among those that did, the differences are striking, albeit perhaps not surprising in light of the reality on the ground. All 35 non-neutral articles on the economy published in Italy present Germany's economy as superior to Italy's, as opposed to only one out of 14 non-neutral articles published in Germany referring to the Italian economy.

Most articles also expressed a neutral view on the quality and functioning of the countries' political system and institutions, more so, again, in Germany (97.7\%) than in Italy (89.5\%) $\left(z=6.65^{\star \star \star}\right)$. When stories were not neutral, the Italian press exclusively (27 stories in total) represented Italy as having an inferior political system and institutional structure to Germany's.

These patterns are confirmed if we compare coverage of individual politicians. There were more articles mentioning at least one Italian politician in the German press (62.9\%) than articles mentioning at least one

\footnotetext{
${ }^{6}$ In the tables and figures in this article, we do not provide percentages when the basis on which they are calculated is less than 10 cases.
} 
German politician in the Italian press (54.3\%) $(z=-1.77$, not statistically significant). When we look at the tone of such coverage (Figure 2), the pattern of a more neutral German press compared to the Italian one is confirmed, as neutral mentions of the other country's politicians constitute 80\% of German newspapers' coverage but only $48.6 \%$ of Italian newspapers' $\left(z=8.45^{\star \star \star}\right)$. In both countries, however, these percentages are lower than for coverage of the countries in general (German press: $84.1 \%$, Italian press: $64.3 \%$, see above), even though the German press is once again substantially more neutral than its Italian counterpart. When we look at the distribution of the non-neutral statements, they are mainly positive when the Italian press speaks about German politicians (60.4\%), but much less so when the German press deals with Italian politicians (34.3\%) $\left(z=2 \cdot 40^{\star}\right)$.

Figure 2 - Treatment of other country's politicians ${ }^{7}$

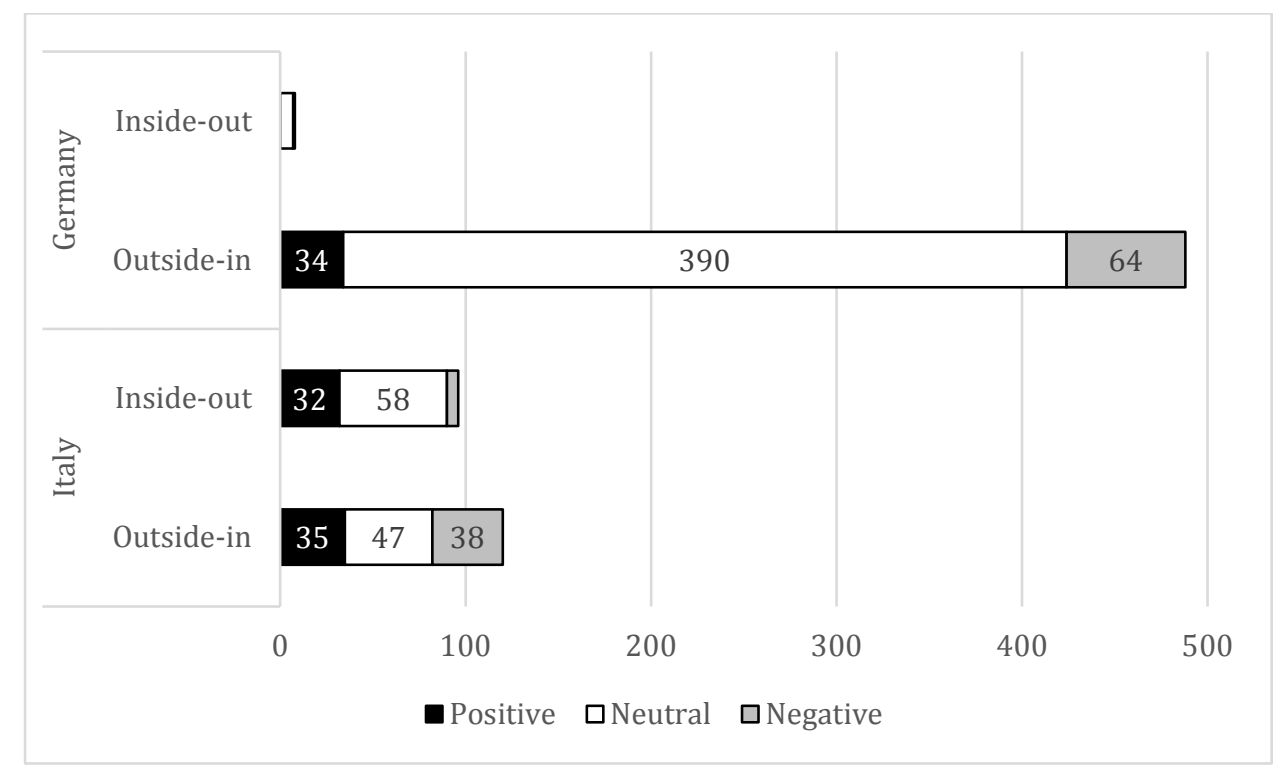

Italian newspapers' portrayal of German politicians deserves further attention. First, the fact that most nonneutral statements about politicians are positive (60.4\%) stands in contrast with the treatment of Germany as a country, where, as discussed above, only $34.8 \%$ of non-neutral stories were positive. Second, there is a striking difference between the tone of coverage of politicians in outside-in and inside-out transnationalisation. While the percentage of positive articles (among non-neutral ones) is $84.2 \%$ for the inside-out mode (i.e., when German politicians are covered in the context of Italian elections), it is only $47.9 \%$ for the outside-in mode (i.e. when German elections are covered). In other words, the Italian press tends to portray German politicians more favourably as part of domestic election coverage than as part of foreign election coverage. Moreover, this is in contrast with how the Italian press portrays Germany as a country (see Figure 1 above): not only is the tone of

\footnotetext{
7 The $\mathrm{N}$ is now different, since the number of politicians mentioned and the number of articles analysed are not identical. Furthermore, note that only politicians of the other country have been considered in this figure.
} 
coverage more negative than positive, but negative coverage is more frequent in the outside-in mode than in the inside-out mode.

All the data presented so far confirm $\mathrm{H} 1 \mathrm{~b}$ and $\mathrm{H} 1 \mathrm{c}$, although with interesting additional insights, such as the predominantly positive representation of German politicians in the Italian press during the Italian election campaign.

Table 3 - Representation of effects of the home on the other country, and of the other country on the home country

\begin{tabular}{|c|c|c|c|}
\hline & & \multicolumn{2}{|c|}{ Country whose newspaper coverage is analysed } \\
\hline & & Italy & Germany \\
\hline \multicolumn{4}{|c|}{ Effects of the home on the other country } \\
\hline \multirow{2}{*}{$\begin{array}{l}\text { Mode of } \\
\text { transnationalisation }\end{array}$} & Inside-out & $\begin{array}{l}11 \text { positive }(8.0 \%) \\
0 \text { no effects } \\
35 \text { negative }(25.3 \%) \\
92 \text { not mentioned }(66.7 \%) \\
\text { Total: } 138\end{array}$ & $\begin{array}{l}2 \text { positive } \\
1 \text { no effects } \\
0 \text { negative } \\
2 \text { not mentioned } \\
\text { Total: } 5\end{array}$ \\
\hline & Outside-in & $\begin{array}{l}3 \text { positive }(2.5 \%) \\
1 \text { no effects }(0.8 \%) \\
2 \text { negative }(1.7 \%) \\
114 \text { not mentioned }(95.0 \%) \\
\text { Total: } 120\end{array}$ & $\begin{array}{l}0 \text { positive } \\
1 \text { no effects }(0.6 \%) \\
8 \text { negative }(4.8 \%) \\
156 \text { not mentioned }(94.5 \%) \\
\text { Total: } 165\end{array}$ \\
\hline \multicolumn{4}{|c|}{ Effects of the other on the home country } \\
\hline \multirow{2}{*}{$\begin{array}{l}\text { Mode of } \\
\text { transnationalisation }\end{array}$} & Inside-out & $\begin{array}{l}13 \text { positive }(9.4 \%) \\
2 \text { no effects }(1.4 \%) \\
21 \text { negative }(15.2 \%) \\
102 \text { not mentioned }(73.9 \%) \\
\text { Total: } 138\end{array}$ & $\begin{array}{l}0 \text { positive } \\
0 \text { no effects } \\
0 \text { negative } \\
5 \text { not mentioned } \\
\text { Total: } 5\end{array}$ \\
\hline & Outside-in & $\begin{array}{l}12 \text { positive }(10.0 \%) \\
3 \text { no effects }(2.5 \%) \\
12 \text { negative }(10.0 \%) \\
93 \text { not mentioned }(77.5 \%) \\
\text { Total: } 120\end{array}$ & $\begin{array}{l}1 \text { positive }(0.6 \%) \\
1 \text { no effects }(0.6 \%) \\
15 \text { negative }(9.1 \%) \\
148 \text { not mentioned }(89.7 \%) \\
\text { Total: } 165\end{array}$ \\
\hline
\end{tabular}

RQ2 asks whether the outside-in and the inside-out mode of transnationalisation is prevalent in the German and Italian press. The total numbers of articles, presented in Table 2 above, offer some useful indications. In Italian 
newspapers, the amount of coverage in the inside-out mode (120 articles, $44.4 \%$ of the total) is similar to that in the outside-in mode (138 articles, 55.6\%). The German data nearly exclusively comprise outside-in coverage (165 articles, $97.1 \%$ of the total). Thus, while the Italian press devoted as much attention to Germany during the Italian campaign as during the German campaign, German newspapers focused on Italy nearly exclusively during the Italian elections, but not during the German elections. This adds to the observation made above that the Italian campaign received more attention in the German press than the German campaign in the Italian press. Furthermore, the slight prevalence of the inside-out mode for the Italian case suggests that press coverage of Germany in Italian newspapers is slightly higher when Italian elections are held than when German elections are held. In other words, the Italian press is more interested in Germany when related to Italian affairs, ${ }^{8}$ but it also recognises that Germany is connected with Italy in important ways. By contrast, the German press does not address such connections, but limits its attention to monitoring the Italian elections in the outside-in mode. In sum, newspapers orient their coverage based on power structures in Europe, which results in asymmetrical levels of transnationalisation, both as a general phenomenon and across the two modes we measured. We return to the implications of this in the conclusion.

Finally, we address $\mathrm{H} 2$, which predicts that the strong variant of transnationalisation - i.e. when media explicitly link the implications of politics in one country to the policies enacted in another country (Koopmans and Erbe 2004) - is more common in the inside-out than in the outside-in mode of transnationalisation.

We first look at the number of articles which discuss Europeanisation at all. Discussion of European integration was more common in the German (48.2\%) than in the Italian press (43.4\%). However, a two-proportion z-test for this difference is not significant $(z=0.98)$. Strong horizontal Europeanisation is indeed more common in the inside-out (49.7\%) than the outside-in mode (43.2\%), as H2 predicts. However, again a two-proportion z-test does not reveal a significant difference in these proportions $(z=1.27)$. Nevertheless, this suggests that public debates about Europe advance better through discussions of foreign countries in domestic elections than by coverage of other countries' elections.

A more precise test of $\mathrm{H} 2$ comes from examining the extent to which the press focused on how much each country affects the other, and whether those effects were presented as positive or negative. Table 3 shows the distribution of the variable measuring coverage of the possible effects of the country's policies on the other country, and of the effects of the other country's policies on the home country. The data support our hypothesis that strong horizontal Europeanisation is more common in the inside-out than in the outside-in mode, even though we have too few articles for the inside-out mode for Germany to warrant iron-clad conclusions. Among the articles in the inside-out mode, 34.3\% mention the possible effects of the home on the other country during the country's domestic elections, while this is the case in only $5.3 \%$ of articles when the other country's election

\footnotetext{
${ }^{8}$ However, it also has to be said that neither the result of the German election not the subsequent government formation were surprising, and the campaign did not feature particularly newsworthy events.
} 
campaign is covered (outside-in mode). When, instead, we look at the other country's effects on the home country, the percentages of articles addressing them are $25.2 \%$ for the inside-out mode and $15.4 \%$ for the outside-in mode. Even though the difference is smaller than in the previous comparison, it is still significant, as a two-proportion z-test reveals $\left(z=2.45^{\star}\right)$. Moreover, if we combine the two variables, the effect of Italy on Germany is presented as negative by both the Italian press (35 out of 46 articles $=76 \%$ ) and the German press (15 out of 17 articles $=88.2 \%$ ). Thus, newspapers' assessments of the implications of interdependencies between Germany and Italy do not differ substantially between the two countries. ${ }^{9}$ Interestingly, however, the Italian press is rather ambivalent on how Germany may affect Italy: in the inside-out mode, 21 articles are negative and 13 positive, and in the outside-in mode, an even number of articles (12) are positive and negative.

\section{Conclusions}

Conceptually, in this study, we aimed at developing the concept of transnationalised political communication beyond existing discussions of the European public sphere, taking into account the different flows of news coverage of elections that occur between countries. The concept of transnationalisation is suited to capturing phenomena of foreign countries playing a role in other countries' politics. We proposed a distinction between outside-in and inside-out modes of transnationalisation. The inside-out mode involves discussion of foreign countries in a country's domestic politics. This is potentially the most novel facet of transnationalisation, as domestic public opinion is becoming increasingly exposed, via both mass and digital media, to information that originates in, or pertains to, other countries. This is distinctive from the outside-in mode, where elections in foreign countries receive some attention and coverage in domestic media.

Our empirical goal was to apply our conceptual map to an exploratory study. We found that transnationalised news coverage of Germany and Italy has different opportunity structures. These can be explained by factors related to the distribution of power and the resulting incentives for political actors to discuss other countries, long-standing cultural representations, and structural characteristics of national media systems. The more powerful country, Germany, was covered more than the less powerful one, Italy. While the more powerful country was featured heavily in coverage of elections in the less powerful country, the reverse was not true at all. The country with a more problematic reputation for effectiveness and reliability, Italy, was covered more negatively than the country with a more solid image, Germany. Finally, the media system that features a lower degree of political parallelism, Germany, produced news stories that were less likely to take an explicitly favourable or unfavourable stance towards the other, Italy, whose press upheld its tradition of political advocacy by offering a more slanted view, in both positive and negative directions, of Germany and of Italy's relationship with it. That the media reflect and respond to power asymmetries, cultural constructs, and the historical conformation of the

\footnotetext{
${ }^{9}$ Note that, with such a design, time-dependent context is kept constant, since the two quadrants refer to the same election.
} 
media-politics nexus is not surprising in light of decades of research on news coverage of domestic politics, but our analysis suggests that these concepts and theories are also helpful for understanding the phenomenon of transnationalisation. As interdependencies between countries become increasingly contentious, for instance in debates over immigration, trade, terrorism, and security, our study suggests that these controversies are likely to be portrayed quite differently, thus potentially leading to cross-country differential effects on both elites and public opinion. Future research should, first, probe the external validity of our findings by comparing a larger number of countries in a longer timeframe and based on a wider variety of news outlets, and, second, test the effects of different types of transnational media coverage on both elites and the public.

We also uncovered relevant empirical differences between news coverage in the inside-out and outside-in modes of transnationalisation. Transnationalisation was more common in its inside-out mode in Italy, but also prominent in the outside-in mode, as Italian newspapers paid close attention to the German 2013 elections. By contrast, transnationalisation in Germany essentially pertained only to the outside-in mode, as Italian elections received some attention in the German press, but there was no corresponding presence of Italian politics in German newspapers' coverage of the German elections (inside-out mode). Our findings suggest that the country that is less powerful, and is "under surveillance", as Italy was in 2013, tends to attract more coverage by media in the more powerful country undertaking the surveillance, than the more powerful country attracts in the less powerful one. By contrast, while the less powerful country pays substantial attention to the more powerful one even during its own elections, the more powerful country essentially ignores the less powerful one when discussing its own elections. The striking asymmetry we found in inside-out transnationalisation thus suggests that important gaps may be left in citizens' understandings of other countries' roles in their own national polities. Transnational public discourse may contribute to enlightening citizens concerning the interdependencies between countries, as opposed to simply reporting about foreign countries to domestic publics, but this is mainly contingent on the focus of the coverage. When media cover other countries' politics and politicians in the context of their own countries' elections, they are more likely to articulate those relationships than when they cover other countries' election campaigns. Considering that voters can be expected to pay more attention to media coverage of their own national campaigns than to coverage of other countries' campaigns - perhaps with the exception of iconic campaigns such as US presidential elections - these findings suggest that news coverage of domestic campaigns may lead voters to learn about other countries and about their countries' relationships with them. However, these patterns are not symmetrical between countries, but linked to power relationships. On the one hand, inside-out transnationalisation seems to be a one-way street where citizens in less powerful countries are likely to be exposed to comments from, and discussion of, more powerful countries during their own national elections, but no corresponding discussion of less powerful foreign countries seems to occur in more powerful countries' domestic campaign news, even at times when those foreign countries may have important effects on domestic politics. On the other hand, outside-in transnationalisation emerged as more of a two-way street by 
which news media help citizens in more powerful countries keep tabs on elections in less powerful countries that can affect their own country, but the reverse also applies in less powerful countries, whose media pay close attention to elections in more powerful countries. The combined implications of these asymmetrical patterns of transnational news coverage may be that citizens (and, to some extent, elites) of less powerful countries are more likely to be informed by their domestic news media of the interdependencies between their and other countries than their counterparts in more powerful countries. It seems normatively problematic that countries at the short end of the straw of transnational power relationships may be better informed of their links with other countries than those with more power. Moreover, if our explanation for these asymmetries in news coverage is correct, we may expect even larger gaps when the comparison involves countries characterised by larger power asymmetries. Even though Italy was in a difficult position in 2013 compared with Germany, other Eurozone countries such as Greece and Portugal were even less powerful. Future research should assess the extent to which our findings from two countries, two elections, and three newspapers per country can be generalised more broadly, as well as the effects of different types of transnational news coverage on elites and voters.

Our study also contributes to research on contemporary domestic and international politics by exploring the nexus between power and public discourse. One intriguing question is whether different dimensions of power may lead to different patterns in transnational information flows. For the most part, the power asymmetries between Germany and Italy discussed here are of a relatively 'hard' nature, rooted as they are in the balance of power in EU politics and the different economic performances of the two countries. However, this leaves open the question whether similar patterns can be expected as a result of asymmetries in 'soft' power (Nye 2004), which is related to less tangible, but potentially consequential resources such as international standing, goodwill, and nation branding. News coverage may be driven as strongly, if not even more strongly, by differences in soft than hard power, and may be more or less sensitive to it depending on the topics being discussed. The nexus between soft power and transnational information flows may also be complicated by the fact that countries aiming to achieve and exercise soft power do so via strategic narratives (Miskimmon, O'Loughlin and Roselle 2014) that include attracting favourable news coverage. While this remains a puzzle to be solved by future theorising and research, the transnational dynamics in public discourse we have identified are crucial to the exercise of all forms of power in contemporary global politics.

\section{References}

Bennett, W. Lance (1990). "Toward a Theory of Press-State Relations in the United States." Journal of Communication 40, 2: 103-27.

De Vreese, Claes H., and Hajo G. Boomgaarden (2006). "Media Effects on Public Opinion About the Enlargement of the European Union." Journal of Common Market Studies 44, 2: 419-36. 
Galtung, Johan, and Mari Holmbue Ruge (1965). "The Structure of Foreign News. The Presentation of the Congo, Cuba and Cyprus Crises in Four Norwegian Newspapers." Journal of Peace Research 2, 1: 64-90.

Gans, Herbert J. (1979). Deciding What's News: A Study of CBS Evening News, NBC Nightly News, Newsweek, and Time. Chicago: Northwestern University Press.

Hallin, Daniel C., and Paolo Mancini (2004). Comparing Media Systems: Three Models of Media and Politics. Cambridge: Cambridge University Press.

Harcup, Tony, and Deirdre O'Neill (2001). "What Is News? Galtung and Ruge Revisited." Journalism studies 2, 2: 261-80.

Hood, Christopher (2010). The Blame Game: Spin, Bureaucracy, and Self-Preservation in Government. Princeton: Princeton University Press.

Hooghe, Liesbet, and Gary Marks (2009). "A Postfunctionalist Theory of European integration: From Permissive Consensus to Constraining Dissensus." British Journal of Political Science 39, 1: 1-23.

lyengar, Shanto (1994). Is Anyone Responsible? How Television Frames Political Issues. Chicago: University of Chicago Press.

Kanji, Gopal K. (2006). 100 Statistical Tests. London et al.: Sage.

Koopmans, Ruud, and Jessica Erbe (2004). "Towards a European Public Sphere? Vertical and Horizontal Dimensions of Europeanized Political Communication." Innovation: The European Journal of Social Science Research 17, 2: 97-118.

Kriesi, Hanspeter, Edgar Grande, Martin Dolezal, Marc Helbling, Dominic Höglinger, Swen Hutter, and Bruno Wüest (2012). Political Conflict in Western Europe. Cambridge: Cambridge University Press.

Maravall, José Maria (1999). "Accountability and Manipulation." In Adam Przeworski, Susan C. Stokes, and Bernard Manin (eds.), Democracy, Accountability, and Representation. Cambridge: Cambridge University Press.

Marks, Gary, and Carole J. Wilson (2000). "The Past in the Present: A Cleavage Theory of Party Response to European Integration." British Journal of Political Science 30, 3: 433-59.

Mazzoni, Marco, and Antonio Ciaglia (2014). "How Italian politics goes popular: Evidence from an empirical analysis of gossip magazines and TV shows". International Journal of Cultural Studies, 17, 4: 381-398.

Miskimmon, Alister, Ben O'Loughlin, and Laura Roselle (2014). Strategic Narratives: Communication Power and the New World Order. London: Routledge.

Nye, Joseph S. (2004). Soft Power: The Means to Success in World Politics. New York: PublicAffairs.

Pew Research Global Attitudes Project (2012). European Unity on the Rocks: Greeks and Germans at Polar Opposites. Available at http://www.pewglobal.org/files/2012/05/Pew-Global-Attitudes-Project-European-CrisisReport-FINAL-FOR-PRINT-May-29-2012.pdf (accessed 14 August 2017).

Poguntke, Thomas, and Paul Webb, eds. (2005). The Presidentialization of Politics: A Comparative Study of Modern Democracies. Oxford: Oxford University Press.

Reuters Institute for the Study of Journalism (2013). Digital News Report 2013. Available at http://reutersinstitute.politics.ox.ac.uk/publication/digital-news-report-2013 (accessed 14 August 2017).

Schuck, Andreas R. T., and Claes H. De Vreese (2006). "Between Risk and Opportunity. News Framing and Its Effects on Public Support for EU Enlargement." European Journal of Communication 21, 1: 5-32.

Van Kempen, Hetty (2007). "Media-Party Parallelism and Its Effects: A Cross-National Comparative Study." Political Communication 24, 3: 303-20. 
Vliegenthart, Rens, Andreas R. T. Schuck, Hajo G. Boomgaarden, and Claes H. De Vreese (2008). "News Coverage and Support for European integration, 1990-2006." International Journal of Public Opinion Research 20, 4: 415-39. 